\title{
Depositional environment of the snow cover on West Antarctic pack-ice floes
}

\author{
M. O. JeFFries, A. L. VEA'ZFY, K. MORRIS \\ Geophysical Institute, University of Alaska-Fairbanks, Fairbanks, AK 99775-7320, U.S.A. \\ H. R. KROUSE \\ Department of Physics and Astronomy, University of Calgary, Alberta T2N 1N4, Canada
}

\begin{abstract}
The depth, density, load and isotopic $\left(\delta^{18} \mathrm{O}\right)$ composition of the snow cover on pack-ice floes were measured in late austral summer 1992 in the castern Ross, Amundsen and western Bellingshausen Seas. Snow-density values commonly exceeded $350 \mathrm{~kg} \mathrm{~m}^{-3}$ and some were as high as $500 \mathrm{~kg} \mathrm{~m}^{-3}$. The densification of the snow occurs quickly and is attributed to a windy environment. The high density and sometimes considerable depth of the snow on the floes accounts for loads of as much as $700 \mathrm{~kg} \mathrm{~m}^{-2}$ and resultant sea-water flooding of the underlying sea ice. Lower mean $\delta^{18} \mathrm{O}$ values in the Ross/Amundsen Seas snow cover suggest that the region might have a cooler climate than the Bellingshausen Sea region. Snow depths on floes in the Bellingshausen Sea region were lower than those in the Ross/Amundsen Seas region, because the Bellingshausen Sea floes were first-year ice. Possible annual units in the isotope profiles of snow, as much as $2 \mathrm{~m}$ deep, indicate that floes in the Ross/Amundsen Seas region were $2-3$ years old.
\end{abstract}

\section{INTRODUCTION}

In February 1991, as USCGC Polar Sea was en route to South America from McMurdo Station, unusually deep snow was observed on many floes in the central Ross Sea (Figs 1 and 2). Unfortunately, it was not possible to go out on the floes to measure the snow depth and other parameters.

In February-March 1992, during a cruise aboard USCGC Polar Sea in the eastern Ross, Amundsen and western Bellingshausen Seas off West Antarctica (Fig. 2), the primary research objective was to investigate the physical propertics, structural characteristics and devel-

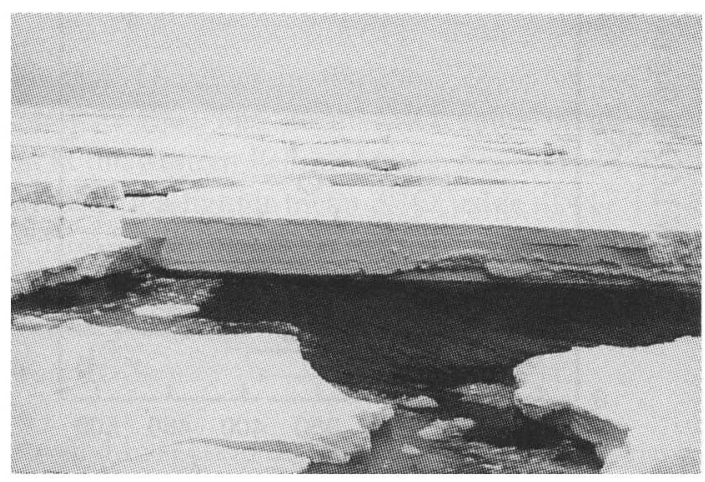

Fig. 1. Deep-snore-covered floe in the central Ross Sea, February 1991. The snow is estimaled to be $1.0-1.25 \mathrm{~m}$ deep and the ice surface is probably depressed below water level, i.e. the floe has a negative freeboard. opment of pack-ice floes (Jeffries and others, 1994). However, deep snow was encountered once again, this time in the eastern Ross Sea and the Amundsen Sea. Thinner snow cover was observed on floes in the western Bellingshausen Sea.

In 1992, for both the Ross/Amundsen and Bellingshausen Seas regions, a data set on snow depth, density, load and oxygen-isotopic variations was compiled. The data set is not large but it is important in view of the relative sparsity of information on the nature of the snow cover on Antarctic sea ice and on snow-sea-ice interactions.

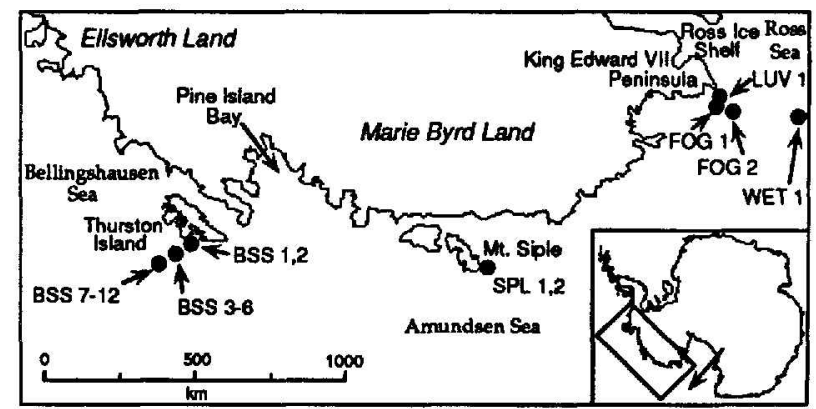

Fig. 2. Map of the location of sampling sites along the coast of Marie Byrd Land and north of Thurston Island, Ellsworth Land, West Antarctica. The inset map shows the location of the study area relative to the rest of Antarctica and the location (arrow) of deep-snow-covered floes observed in the central Ross Sea in February 1991. 


\section{STUDY AREA AND METHODS}

From mid-February to mid-March 1992, USCGC Polar Sea passed along the coast of Marie Byrd Land to Pine Island Bay before entering the western Bellingshausen Sea north of Thurston Island (Fig. 2). Snow samples and ice cores were obtained from floes near King Edward VII Peninsula, Mount Siple and in the western Bellingshausen Sea (Fig. 2).

At each site, a snow pit was excavated, the snow depth was measured and snow samples werc removed using a $58 \mathrm{~mm}$ diameter, $500 \mathrm{~cm}^{-3}$ snow tube. A continuous sequence of snow samples was taken from the top to the base of the snow cover at each location. At sites where the ice surface was flooded and the base of the snow cover was soaked with sea water (LLV-1, FOG-1, FOG-2, WET-1, SPL-1, SPL-2 BSS-2), sampling stopped at the top of the soaked snow layer. Once samples were removed from the snow cover, the snow and tube werc weighed and the density determined. These samples were then melted and placed in storage for later oxygen-isotope analysis. All sites were measured for density and isotopes, except LLV1 and WET-1.

A total of 76 and 58 density measurcments was made in the Ross/Amundsen and Bellingshausen Seas regions, respectively. A total of 93 and 59 oxygen-isotope measurements was made on samples from the Ross/ Amundsen and Bellingshausen Seas regions, respectively.

The oxygen isotope or ${ }^{18} \mathrm{O} /{ }^{16} \mathrm{O}$ ratios of melted samples was measured by mass spectrometer. They are expressed as $\delta^{18} \mathrm{O}$ in units of parts per thousand $(\%$ ). $\delta^{18} \mathrm{O}$ is the difference between the ratio of the heavy to light isotope in the sample and the isotopic ratio of a standard (V-SMOW, $\delta^{18} \mathrm{O}=+0.07 \%$ ).

\section{SNOW GHARACTERISTICS}

\subsection{Snow depth}

In the central Ross Sea (Fig. 2), in February 1991, the surface of the snow cover on the majority of floes was estimated to bc $0.3-2.0 \mathrm{~m}$ above water level. The depth of the snow and the character of the snow surface gave the floes a high, flat-topped appearance that was accentuated by the vertical walls of the margins of the snow cover (Fig. 1). Distinct layers and occasional overhangs were visible in the walls (Fig. 1). Many deep snow-covered floes, with characteristics similar to those seen the previous year in the central Ross Sea, were observed in February 1992 in the eastern Ross Sca and Amundsen Sea, offshorc from Maric Byrd Land (Fig. 1). Commonly, the snow cover was $1-2 \mathrm{~m}$ deep (estimated) but a few floes had 3-4 m (estimated) deep snow cover. Measured snow-depth values varied between 1.56 and $1.98 \mathrm{~m}$ (mean, $1.5 \pm 0.49 \mathrm{~m}$ ) in the Ross/ Amundsen Seas region, and between 0.16 and $0.7 \mathrm{~m}$ (mean, $0.34 \pm 0.15 \mathrm{~m}$ ) in the Bellingshausen Sea region (Fig. 3). There were no in-dications of melting, either at the snow surface (e.g. melt ponds) or within the snow cover (e.g. ice layers, lenses, pipes) in any region in 1991 and 1992.

\subsection{Snow density and snow load}

The minimum and maximum individual density values

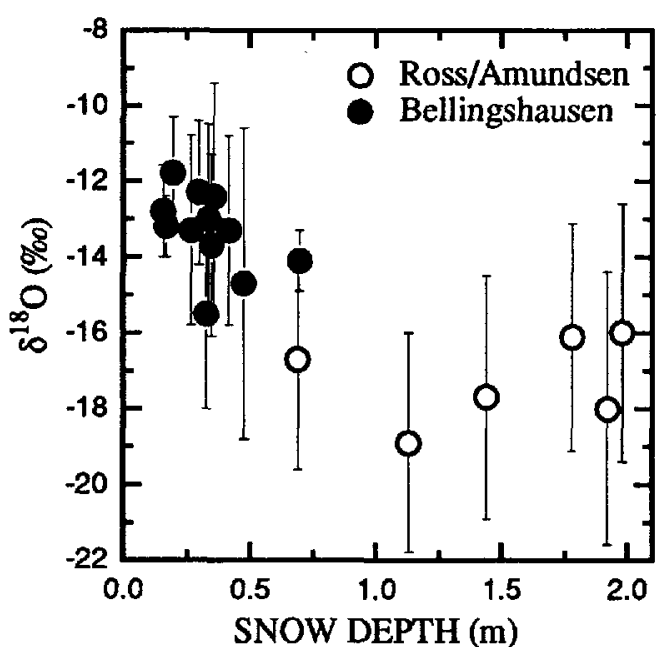

Fig. 3. Scatter plot of snow depth is $\delta^{18} O$ (mean \pm 1 standard deviation).

were 91 and $543 \mathrm{~kg} \mathrm{~m}^{-3}$, respectively. The lowest values occurred in soft, fresh snow. The highest values were associated with hard snow that fractured conchoidally during pit excavation. Mean density values of individual pits varied between $240 \pm 51$ and $446 \pm 41 \mathrm{~kg} \mathrm{~m}^{-3}$ (Fig. 4). The highest-density values were observed in the Ross/

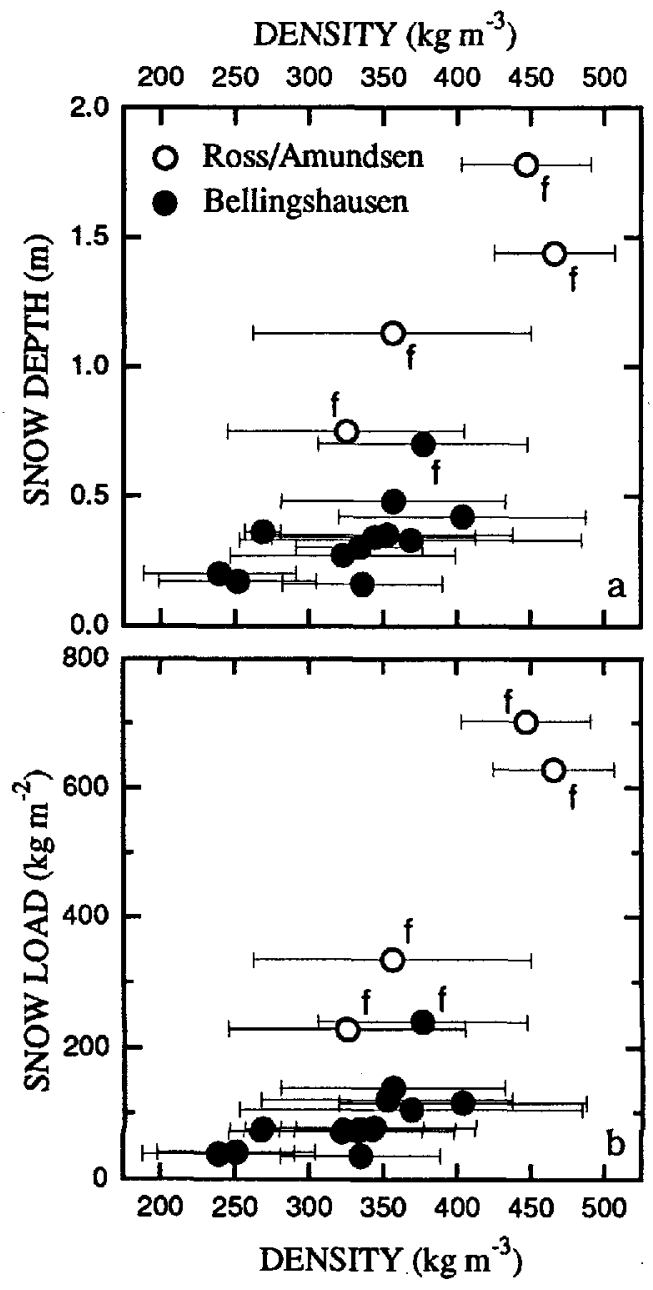

Fig. 4. Scatter plots of density (mean \pm 1 slandard deviation) us lotal snow depth (a) and snow load (b). Those floes which were flooded with sea water are identified by a letter " $f$ ". 


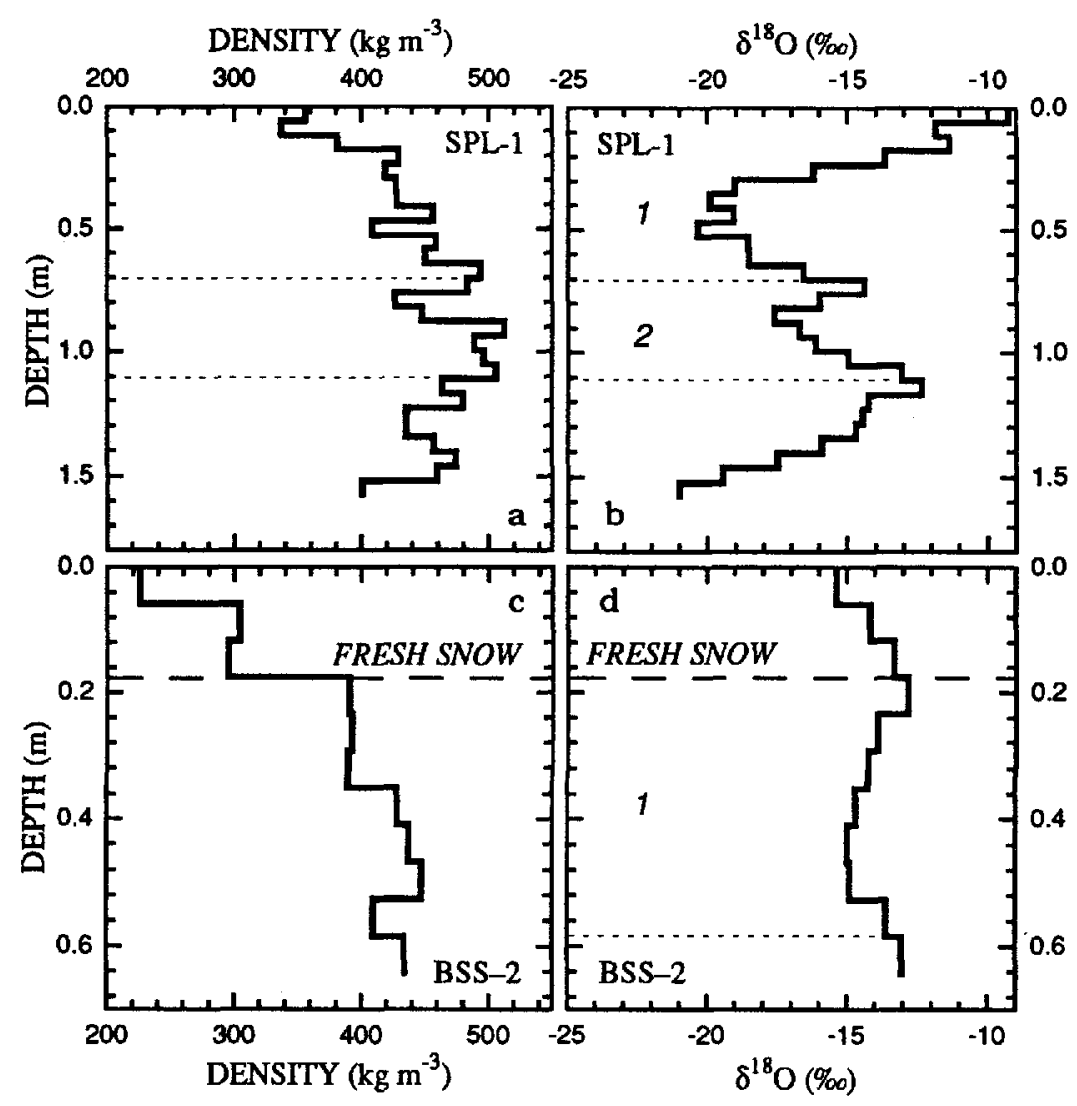

Fig. 5. Density and $\delta^{I \delta} O$ as a function of depth in the snow cover at sites SPL-1 and BSS-2. Possible annual units in the $\delta^{18} O$ profiles are identified by horizontal, fine dashed lines and numbers in italics. For SPL-1, the dashed lines have been extrapolated across to the density profile to illustrate the poor correlation between isolopic minima and maxima and density minima and maxima.

Amundsen Seas region but overall the difference between the Ross/Amundsen and Bellingshausen Seas density data is small (Fig. 4).

The data indicatc that the snow load was greater in the Ross/Amundsen Seas region (Fig. 4b). In the Bellingshausen Sea region, the total load on floes varied between 39 and $242 \mathrm{~kg} \mathrm{~m}^{-2}$ (mean $88 \pm 58 \mathrm{~kg} \mathrm{~m}^{-2}$ ), whereas it varied between 277 and $702 \mathrm{~kg} \mathrm{~m}^{-2}$ (mean $472 \pm 197 \mathrm{~kg} \mathrm{~m}^{-2}$ ) in the Ross/Amundsen Seas region (Fig. 4b). The mean snow-load values are conservative at those sites where the base of the snow cover was not sampled, because it was soaked with sea water (Fig. 4).

\subsection{Stable-isotopic composition}

Individual $\delta^{18} \mathrm{O}$ values in the snow cover varied between -22.8 and $-9.1 \%$. The mean $\delta^{18} \mathrm{O}$ value of all the snow samples in the western Bellingshausen Sea was $-13.5 \pm 2.4 \%$ compared with a lighter mean $\delta^{18} \mathrm{O}$ value of $-17.1 \pm 3.1 \%$ for the Ross/Amundsen Seas region (Fig. 3).

\subsection{Density and $\delta^{18} \mathrm{O}$ variations as a function of depth}

It was noted in section 3.1 that distinct layers were visible in the walls of the deep snow cover in the Ross/Amundsen Seas region (Fig. 2). Layering was also evident in the density and isotope profiles in that region. For example, at site SPL-1, distinct maxima and minima in the isotope profile suggest there are two full layers, plus part of a third at the base of the snow cover (Fig. 5b). Extrapolating the lines identifying the isotopic layers across to the density profile shows that density minima and maxima occur within one isotope layer, i.e. at best, there is a poor correlation between the density and isotope profiles (Fig. $5 \mathrm{a}$ and $\mathrm{b}$ ).

Other than fresh snow at the surface, there was less evidence of layering in the density profiles of Bellingshausen Sea sites (Fig. 5c). The only site in the Bellingshausen Sea region, where isotope maxima and minima indicated the presence of layering (one layer), was at BSS-2 (Fig. 5d). At the majority of Bellingshausen Sea sites, the most negative $\delta^{18} \mathrm{O}$ values occurred at the base of the snow cover and becamc more positive towards the surface (Fig. 6).

\section{DISCUSSION}

\subsection{Snow density and snow load}

Apart from low-density layers of fresh snowfall, the snow cover often had an extremely high density, with many values exceeding those quoted by Paterson (1981) for wind-packed snow $\left(350-400 \mathrm{~kg} \mathrm{~m}^{-3}\right)$. The occurrence of conchoidal fracture during pit excavation and the character of the walls of the snow cover (Fig, I) suggest a mechanically competent material. It is unlikely that the high densities are due to overburden pressure. For example, a density of $400 \mathrm{~kg} \mathrm{~m}^{-3}$ occurs at only $0.2 \mathrm{~m}$ 


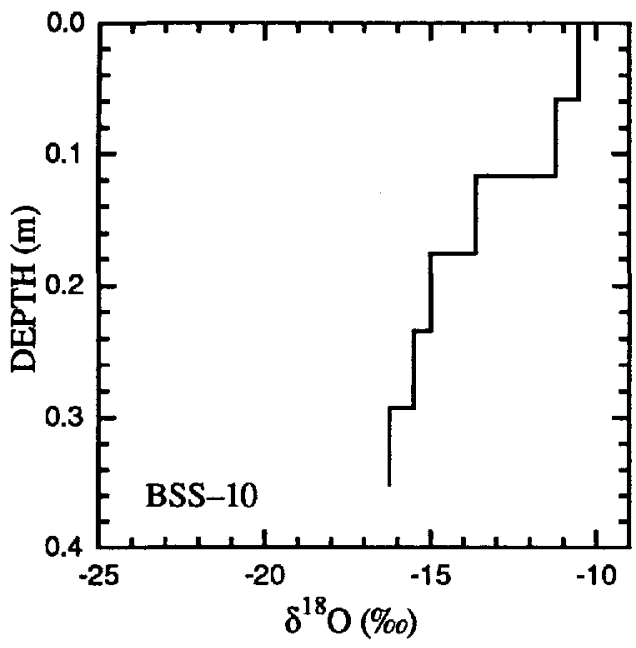

Fig. 6. Oxygen-isolope profile at site BSS-10 in the western Bellingshausen Sea.

below the surface at SPL-2 (Fig. 5a); $0.2 \mathrm{~m}$ of snow would provide insufficient compressive stress to densify the snow. It is more likely that the high density values are evidence of snow deposition in a windy environment. The layered charactcr of the dense, mechanically competent snow and the conchoidal fractures observed during snow-pit excavation are strong evidence that the snow cover had been subject to strong winds.

The high density and often considerable depth of the snow would account for the high snow loads on the floes and the flooding that was encountered during sampling (Fig. 4b). Heavy snow loads and consequent flooding are instrumental in the formation of snow-ice at the surface, a means by which Antarctic floes increase their thickness from the top upwards (Jacka and others, 1987; Lange and others, 1990; Lange and Hubberten, 1992; Jeffries and Weeks, 1993; Jeffries and others, 1994). Except for site WET-1, snow-ice layers were found at the top of all the floes, whether they were flooded or dry at the time of sampling in 1992, indicating the role of the snow cover in sea-ice development in this region of the Southern Ocean (Jeffries and others, 1994).

\subsection{Snow depth and age of the ice}

A comparison of the snow-depth data with reports from other sea-ice regions of the Southern Ocean indicates that, whereas the amount of snow on floes in the Bellingshausen Sea region is not unusual, the deep snow cover observed in the Ross/Amundsen Seas region is generally greater than amounts reported elsewhere (Wadhams and others, 1987; Lange and Eicken, 1991; Jeffries and Weeks, 1993; Allison and others, 1993). That such deep snow should have been encountered in the Ross/Amundsen Seas region and that it should have exceeded that in the Bellingshausen Sea region was unexpected.

Onc reason for the surprise at the amount of snow is the simple fact that there have been few if any reports of such deep snow on either Antarctic or Arctic ice floes. The second reason is that the ice sheet adjacent to the Bellingshausen Sea has the highest surface balance of all Antarctica, and scaward extrapolations from the con- tinental-surface balance suggest that a greater amount of snow might be expected on the Bellingshausen Sea ice that on the Ross/Amundsen Seas ice (Giovinetto and Bentley, 1985; Giovinetto and others, 1992).

The most likely explanation for the snow-depth contrast between the Ross/Amundsen and the Bellingshausen Seas regions is a difference in the age of the icc. Anomalous ice conditions occurred in the Bellingshausen Sea in the austral summer of 1991 , when it was almost icefree (Jacobs and Comiso, 1993). Consequently, the majority of the flocs that were investigated in the late austral summer of 1992 were probably barely 1 year old and had not existed long enough for a deep snow cover to accumulate on them. In a "normal" sea-ice year, perhaps a greater depth of snow might be observed on Bellingshausen Sea floes. Only future observations will determine whether or not this is the case.

\subsection{Isotopic variations}

Seasonal, temperature-dependent variations in the oxygen-isotopic composition of precipitation, when winter precipitation with more negative $\delta^{18} \mathrm{O}$ values than summer precipitation creates annual units in the snow and ice, are important glaciological phenomena that have been used widely in ice-core studies of palaeo-environmental change (c.g. Dansgaard and others, 1973). Lange and Hubberten (1992) reported isotopic minima and maxima in Weddell Sea ice snow cover and suggested they also represented annual units. It is quite possible that, despite the evidence for a windy depositional environment and potential for crosion and redistribution of snow, the isotopic minima and maxima observed in the Ross/Amundsen Seas snow cover (Fig. 5b) and at the Bellingshausen Sea site BSS-2 (Fig. 5d) represent winter and summer precipitation, i.e. there are annual units in the snow cover. The maximum number of annual units observed in the snow cover was two, plus an incomplete unit (Fig. 5b). This was typical of the Ross/Amundsen Seas snow cover and suggests 2-3 years of snow accumulation on ice of a similar age.

It is not uncommon for a single annual unit identified in an isotope profile to contain both density minima and maxima, e.g. SPI-2 (Fig. 5a). Benson (1962) drew attention to this fact and explained that it is due to the effects of individual storms and high winds. If the high density values in the study area are due to wind action, then the density layers observed in the snow cover might be a record of fluctuations in wind intensity or storminess in this region, and the layers observed in the walls of the snow cover and in the density profiles might represent individual wind slabs.

The form of the isotope profiles in the Bellingshausen Sea snow cover is probably additional evidence for the young age of the Bellingshausen Sea ice. Only the snow cover at BSS-2 (Fig. 6d) had a recognizable annual unit. Otherwise, the trend from the most negative $\delta^{18} \mathrm{O}$ values at the base of the snow cover to more positive $\delta^{18} \mathrm{O}$ values at the surface (Fig. 6) suggests there is less than a full year's accumulation on the other floes. Assuming that the most negative $\delta^{18} \mathrm{O}$ values at the base of the snow cover represent accumulation during particularly cold conditions, the ice might have started to form and snow 
accumulation to begin in mid-winter rather than early winter.

There are few continental isotope data with which to compare the marine-isotope data. Morgan (1982) has summarized the geographic distribution of mean $\delta^{18} \mathrm{O}$ values in the surface layers of the Antarctic ice sheet but the data are primarily for inland, high-clcvation arcas, and there are no data for the coastal regions of Marie Byrd and Ellsworth Lands. For a comparison of marine $\delta^{18} \mathrm{O}$ values, there are the late-winter Weddell Sea data of Lange and Hubberten (1992): mean $\delta^{18} \mathrm{O}$ values for the snow cover at 23 individual sites range from -22.5 to $-10.5 \%$ and the mean of all the sites is $-16.5 \pm 3.3 \%$ these values are interpolated from Figure 3 (Lange and Hubberten, 1992)). Thesc data are not dissimilar to those found in the present study, particularly in the Ross/ Amundsen Scas snow cover (mean $\delta^{18} \mathrm{O},-17.1 \%$ ). However, the mean $\delta^{18} \mathrm{O}$ value of the Bellingshausen Sea snow cover is $3 \%$ more positive than the mean $\delta^{18} \mathrm{O}$ value of the Weddell Sea and the Ross/Amundsen Scas snow cover.

Since the isotopic composition of precipitation is temperature-dependent (Dansgaard and others, 1973), the more positive $\delta^{18} \mathrm{O}$ values of the snow cover on the Bellingshausen Sea floes comparcd to the Ross/Amundsen Seas and Weddell Sea floes (Fig. 3) might be due to a climatic difference between the regions. A simple latitude effect, with more-negative $\delta^{18} \mathrm{O}$ values expected at more southerly, colder latitudes (Dansgaard and others, 1973), does not apply to the difference between the Bellingshausen and Weddell Seas samples. Although the Bellingshausen Sea sites were located between $70.55^{\circ}$ and $71.56^{\circ} \mathrm{S}$, the snow-cover $\delta^{18} \mathrm{O}$ values are more positive than those recovered from Weddell Sea floes located further north between about $63^{\circ}$ and $70.3^{\circ} \mathrm{S}$.

Seaward extrapolation of continental coastal mean annual temperatures suggests that the Ross/Amundsen Seas and Weddell Sea regions might be $5-10^{\circ} \mathrm{C}$ cooler than the Bellingshausen Sea region Giovinetto and others, 1990). With regard to the Weddell Sea, the Antarctic Pcninsula is known to act as a climatic divide between the Bellingshausen and Weddell Seas regions, creating barrier winds and coolcr temperatures along the eastern Weddell Sea side of the peninsula and warmer temperatures along the western Bellingshausen Sea side (Schwerdtfeger, 1984). The separation of the Weddell and Bellingshausen Seas by the Antarctic Peninsula also emphasizes the fact that the Weddcll Sca is in the Atlantic Ocean sector of the Southern Ocean and the Bellingshausen Sea is in the Pacific Ocean sector. Consequently, it is possible that each region has a different moisture source. The same might apply to the Ross/Amundsen and Bellingshausen Seas regions

There is some evidence that the Bellingshausen Sea region has a warmer climate than the Ross/Amundsen and the Weddell Seas regions. However, in view of the difference in the number of samples in the Ross/ Amundsen and Bellingshausen Seas data sets, the age difference of the snow cover from which the samples wcrc recovered and the evidence for a windy depositional environment, a definitive statement on the climatic implications of the isotopic difference between the snow covers must wait for additional data to be obtained when "normal" sea-ice conditions prevail in each area. A possible moisturc-source effect on the isotopic composition of precipitation on Antarctic sea ice requires more information on atmospheric circulation than is presently available.

\section{GONCLUSION}

The first data on the depth, density, load and isotopic composition of the snow cover on pack-ice floes at the end of summer in the eastern Ross, Amundsen and western Bellingshausen Seas have been presented. Although the data set is small, it indicates the potential value of information on the characteristics of the snow cover on sea ice. Snow densification to values of as much as $500 \mathrm{~kg} \mathrm{~m}^{-3}$ seems to occur in a short period of time, most probably due to strong winds. The isotopic data suggest that the Bellingshausen Sea region might have a slightly warmer climate than the Ross/Amundsen and the Weddell Seas regions. In both the Ross/Amundsen Seas and the Bellingshausen Sea regions, a heavy load of deep, dense snow can accumulate on the perennial ice, causing flooding. Although there is strong evidence that snow deposition and metamorphism occurs in a windy environment, isotopic minima and maxima in the snow cover might represent annual units and a means to estimate the age of the snow cover and the ice.

\section{ACKNOWLEDGEMENTS}

'I'his study was funded by the Ocean and Climate Systems Program, Division of Polar Programs, U.S. National Science Foundation grant No. DPP-8915863. We thank Captain C. G. Boyer (commanding officer), the officers and crew of USCGC Polar Sea for welcoming us aboard and contributing to the success of our work. There is too little space to name them all but we are particularly grateful to the many U.S. Coast Guard personnel who worked hard in their frec time assisting us on the ice. The stable-isotope laboratory at the University of Calgary is funded by the Natural Science and Engineering Research Council of Canada. M. Sturm kindly read an carly version of the manuscript and, together with $\mathrm{C}$. Benson, provided advice on the interpretation of the data.

\section{REFERENCES}

Allison, I., R. E. Brandt and S. G. Warren. 1993. East Antarctic sea ice: albedo, thickness distribution and snow cover. 7. Geophys. Res., $98(\mathrm{C}: 7), 12,417-12,429$.

Berson, C.S. 1962. Stratigraphic studies in snow and firn of the Greenland ice sheet. SIPRE Res. Rep. 70.

Dansgaard, W., S.J. Johnson, H. B. Glausen and N. Gundestrup. 1973. Stable isotope glaciology. Medd. om Groni., 197(2), 1-53.

Giovinetto, M. B. and C.R. Bentley. 1985. Surface balance in ice drainage systems of Antarctica. Antart. J. U.S., 20(4), 613.

Giovinetto, M. B., N. M. Waters and C. R. Bentley. 1990. Dependence of Antarctic surface mass balance on temperature, elevation and distance to open ocean. $\tilde{J}$. Geophys. Res., 95(D4), 3517-3531.

Giovinetto, M. B., D. H. Bromwich and G. Wendler. 1992. Atmospheric net transport of water-vapor and latent-heat across $70^{\circ} \mathrm{S} .7$. Geophys. Res., 97(D) ), 917-930.

Jacka, T.H.; I. Allison, R. Thwaites and J.C. Wilson. 1987. 
Jeffries and others: Depositional environment of snow cover on West Antarctic pack-ice floes

Characteristics of the seasonal sea-ice of East Antarctica and comparisons with satcllite observations. Ann. Glacial., 9, 85-91.

Jacobs, S. S. and J. C. Comiso. 1993. A recent sea-ice retreat west of the Antarctic Peninsula. Geophys. Res. Lett., 20 12), 1171-1174.

Jeffries, M. O. and W. F. Weeks. 1993. Structural characteristics and development of sea ice in the western Ross Sea. Antart. Sci, 5(1), 6375.

Jeffries, M. O., R. O. Shaw, K. Morris, A. L. Veazey and H. R. Krouse. 1994. Crystal structure, stable isotopes $\left(\delta^{18} \mathrm{O}\right)$ and development of sea ice in the Ross, Amundsen and Bellingshausen Seas, Antarctica. 7. Geophys. Res., 99(C1), 985995.

Lange, M. A. and H. Eicken. 1991. 'l'he sea ice thickncss distribution in the northwestern Weddell Sea. J. Geophys. Res., 96(C3), 4821-4837.

Lange, M. A. and H. -W. Hubberten. 1992. Isotopic composition of sea ice as a tool for understanding sea ice processes in the polar regions. In Macno, N. and T. Hondoh, eds. Physics and chemistry of ice. Sapporo, Japan, Hokkaido University Press, 399-405.
Lange, M.A., P. Schlosser, S. F. Ackley, P. Wadhams and G.S. Dicckmann. 1990. ${ }^{18} \mathrm{O}$ concentrations in sea ice of the Weddell Sea, Antarctica. f. Glaciol., 36(124), 315-323.

Morgan, V. I. 1982. Antarctic ice-shect surface oxygen-isotope values. $J$. Glaciol., 28(99), 315-323.

Paterson, W. B. 1981. The physics of glaciers. Second edition. Oxford, etc., Pergamon Press.

Schwcrdtfeger, W. 1984. Weather and climate of the Antartic. Amsterdam, Elsevier.

Wadhams, P., M.A. Lange and S.F. Acklcy. 1987. The ice thickness distribution across the Atlantic sector of the Antarctic Ocean in midwinter. 7. Geophys. Res., 92(C13), 14,535-14,552.

The accuracy of references in the text and in this list is the responsibility of the authors, to whom queries should be addressed. 